\title{
Evaluation of Chemistry and Concentration of Air Pollutants from Brick Factories in Nahrawan Area, Northeast Baghdad, Using GIS Methods
}

\author{
Bassim M. Hashim*, Esam A. Abdulwahed and Maitham A. Sultan \\ Ministry of Science and Technology, Baghdad-Iraq. \\ *Corresponding Author: bassim_saa22@yahoo.com
}

\begin{abstract}
This study aimed to measure the concentration of the total suspended particle (TSP) and gaseous pollutants $\left(\mathrm{CO}, \mathrm{CO}_{2}, \mathrm{SO}_{2}\right.$ and $\left.\mathrm{NO}_{2}\right)$ that emitted from Nahrawan's brick factories and compare it to its counterparts from the village of Nahrawan. Samples from 17 sites, as well as Nahrawan village were collected in the current study. The results showed that TSP had the highest concentration $\left(9801.7 \mu \mathrm{g} / \mathrm{m}^{3}\right)$, exceeding world health organization (WHO) standard in all study sites, including Nahrawan village. The results also indicated that $\mathrm{CO}$ concentration at most sites exceeded WHO standard. The results showed that $\mathrm{CO}_{2}$ concentration in all the sites exceeded WHO standard $(250 \mathrm{ppm})$, while the measure taken from Nahrawan village registered lower. $\mathrm{SO}_{2}$ was not record in air of Nahrawan village, yet it formed the highest concentration $(0.1 \mathrm{ppm})$ in the study area, much greater than the WHO standard $(0.01 \mathrm{ppm})$. On the other hand, $\mathrm{NO}_{2}$ assumed the highest concentration of $(0.3 \mathrm{ppm})$ again, higher than WHO standard of $(0.11 \mathrm{ppm})$ across all sites, except Nahrawan village. Spatial analysis was performed to generate spatial patterns of air pollutants released by bricks factories in Nahrawan region and to represent the values of wind speed. Visualization of the spatial patterns revealed that the pollutants highly concentrated in the central and southern study area and is located towards the prevailing wind.
\end{abstract}

[DOI: 10.22401/ANJS.21.4.03]

Keywords: Air pollutants, bricks factories, spatial analysis.

\section{Introduction}

Brick is one of the most important materials for the construction industry. The conventional method of bricks production has brought undeniable shortcomings. The consumption of earth-based materials as clay, shale and sand in brick production resulted in resource depletion, health effects, environmental degradation, and energy consumption $[1,2]$. Production of bricks results in environmental degradations due to emission of significant quantities of gaseous and particulate pollutants [3]. Pollution has become a phenomenon in all its forms and norms imposed reality in our society and our cities, which constitutes an obsession with the stakeholders and motivation to work to find quick solutions and appropriate, with the growing problems and risks resulting there from significantly in recent times, especially as the major cause of pollution due to economic and population growth and concomitant social activities, commercial and industrial. The industries that contribute to the pollution of the environment in a large, bricks industry, which result in the dust of many lead to air pollution and low quality with the consequent increase in diseases affecting public health. Know the environment as a set the elements that surround and affect the living and affected by it, and most important of these vital elements: the water, air and soil [4]. Also known as air pollution that the change in concentration of components of air, directly or indirectly, in natural or artificial so as to lead to damage to the environment and its components and its various components [5].

Nahrawan area is consists of more than 200 of the bricks factories eligibility has been established since 1985, where the transfer of these plants from the Taji area to the area of Nahrawan, for two reasons: first, the prevailing wind direction in Iraq is from the northwest to southeast and then carrying contaminants away from Baghdad. The other reason is presence of large areas of clay soil viable for the manufacture of bricks, so each factory has identified a specific area to rip the soil [6]. 
The most of air pollutants emitted from brick factories include TSP and $\left(\mathrm{CO}, \mathrm{CO}_{2}\right.$, $\mathrm{SO}_{2}$ and $\mathrm{NO}_{2}$ ) gases, caused by fuel oil use (the worst kind of fuel), to completion of the burning process. The brick industry in Iraq is still using primitive methods, such as animal use, old combustion systems, with absence of treatment units [7]. The releases of toxic substances from these brick kilns are adversely affecting soil, plants, animals and people in their surroundings being the most severe for brick workers, children and women [8]. With geographic information system (GIS), the area and the level affected by air pollution can be displayed more precisely and objectively. GIS technology allows locating the pollutants source and monitor those areas for change to conserve the quality of air, providing boundary condition to the air quality models was done by using GIS, furthermore using of GIS modeling in air pollution for processing the surface data [9].

There are many studies deals with emitted of air pollutants from bricks industry. (EL Essa, 2011) suggested air pollution in the province of Karbala, because of there are brick factories 11 and the furnace 168. The results noted that 7 of these factories were located northwest of Karbala city and the wind direction for a period of 6 months is the northwest, which helps to speed the chemical reaction and the presence of high-speed wind helps increase the rates of pollution.

(Skinder et al, 2014) monitored of brick kiln emissions on 8 hourly basis to estimate the pollution level of $\left(\mathrm{SO}_{\mathrm{X}}, \mathrm{NO}_{\mathrm{X}}\right)$, and TSP in district Budgam, Jammu and Kashmir state (India). The results revealed that all pollutants were crossing the limits prescribed by National Ambient Air Quality Standards (NAAQS). Further, the air quality index (AQI) was calculated and the study sites were categorized from severe to high pollution including residential areas which is of most concern in respect to health conditions of the local people. (Flores, 2017)[10], studied pollutants such as $\left(\mathrm{SO}_{2}, \mathrm{NO}_{2}, \mathrm{H}_{2} \mathrm{~S}, \mathrm{CO}\right.$ and PM10), which they were expelled by the brick factory located in the town of San Pedro de Carabayllo, Lima, Peru. The results of $\mathrm{SO}_{2}$ were $\left(13.3 \mu \mathrm{g} / \mathrm{m}^{3}\right)$, $\mathrm{H}_{2} \mathrm{~S}\left(6.9 \mu \mathrm{g} / \mathrm{m}^{3}\right)$, CO $\left(2024.6 \mu \mathrm{g} / \mathrm{m}^{3}\right)$, NOx $\left(13.6 \mu \mathrm{g} / \mathrm{m}^{3}\right)$ and PM10 $\left(105 \mu \mathrm{g} / \mathrm{m}^{3}\right)$. These values are within the national standards of air environmental quality.

The aim of the present study is to assess the air quality of the study area by measuring the concentration of gaseous pollutants and TSP that were emitted from brick factories and compare them with WHO standard and study the effect of wind speed and direction on the movement of air pollutants. In addition, the study uses spatial analysis to create a spatial model in GIS of air pollutants released by Nahrawan bricks factories for visualization and intuitive evaluation.

\section{Study Area}

Nahrawan area is located to the east of Baghdad at about $(35 \mathrm{~km})$. Nahrawan area containing a large industrial area larger than an extended (40000 acres) belonging to the Industrial Development Corporation, where the spread in which more than 200 brick factories and each factory has identified a specific area for the extraction and production of bricks. The residential area of Nahrawan village located at a distance of about $(15 \mathrm{~km})$ to the west of the industrial area. The Fig.(1) shows sites of air pollutants measurement in Nahrawan bricks factories of the current study. 

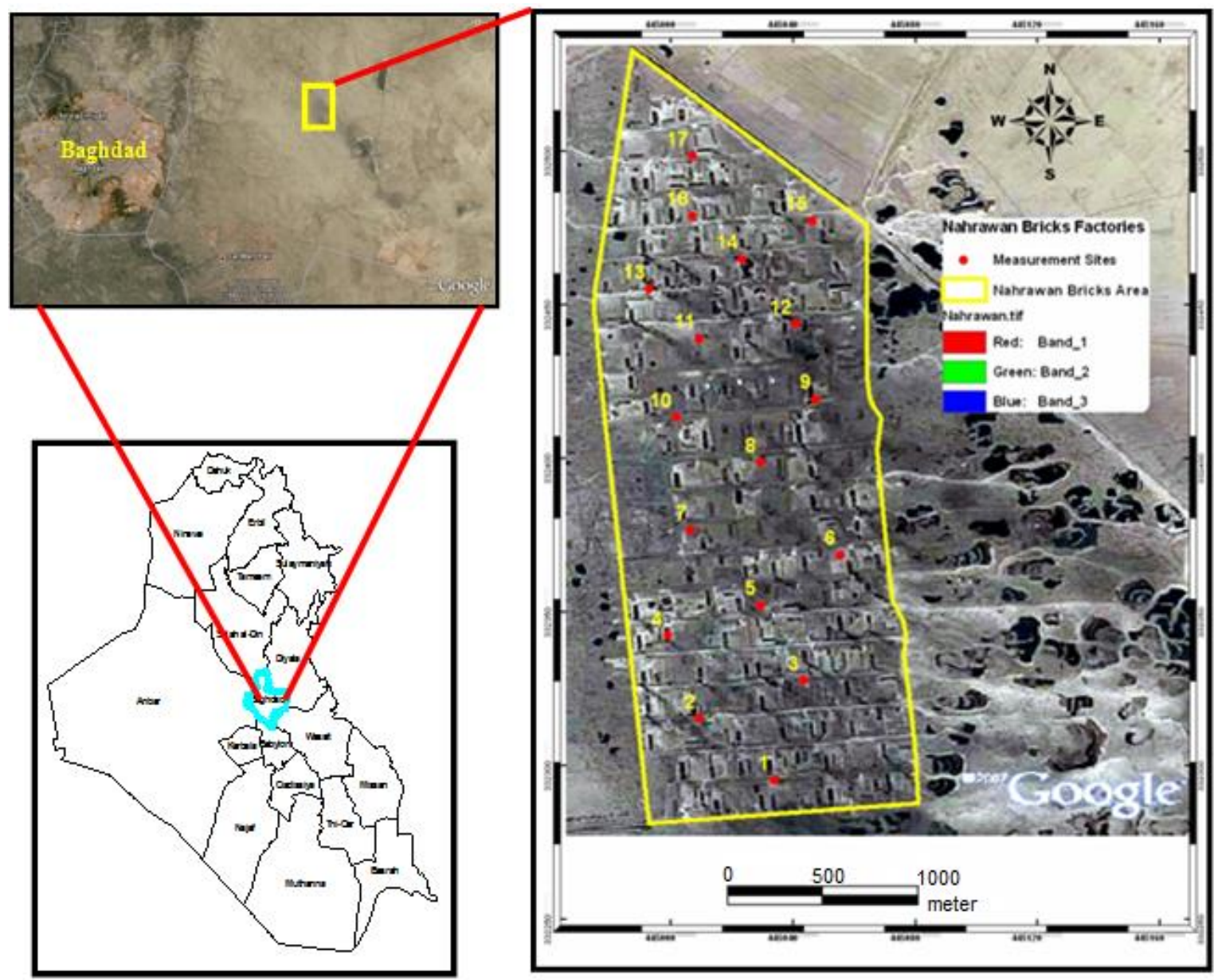

Fig. (1): Google earth image showed sites of air pollutants measurement in Nahrawan bricks factories.

\section{Materials and Methods}

Pollutant concentration recorded at 17 measurement sites was distributed on different locations in Nahrawan bricks factories. The Low Volume Sample device (Sniffer/L-30), (Rotheroe \& Mitchll Co. Ltd, USA), was used for the collection of TSP on cellulose filters (Whitman type) by diameter $(6 \mathrm{~cm})$. The average of air flow input to device (40-70 liter/min). The following equations used to calculate TSP concentration [11]:

$$
\begin{gathered}
\text { TSP Concentration }=\left(\frac{w_{2}-w_{1}}{V_{T}}\right) \times 10^{6} \ldots \ldots(1) \\
V_{T}=\left(\frac{V_{1}+V_{2}}{2}\right) \times \frac{t}{1000} \ldots \ldots(2)
\end{gathered}
$$

Where $\left(V_{T}\right)$ the total volume of air drawn unit $\left(\mathrm{m}^{3}\right),\left(\mathrm{w}_{1}\right)$ weight of filter before air flow, $\left(\mathrm{w}_{2}\right)$ weight of filter after air flow, $\left(\mathrm{V}_{1}\right)$ volume of air drag the beginning of the unity (liter/min), $\left(\mathrm{V}_{2}\right)$ volume of air the end of the drag unit (liter/min), (t) the time it takes to withdraw (60 min). Used portable device (TSI, IAQ-CALC 8762, USA), to measure concentration of $\left(\mathrm{CO}\right.$ and $\left.\mathrm{CO}_{2}\right)$. NOVA device (65690 RHTK) used to measure $\left(\mathrm{SO}_{2}\right.$ and $\mathrm{NO}_{2}$ ). Polluted gases measuring were in parts per million (ppm). As well as used GPS device, (Garmin, USA) to limitation the measurement sites of air pollutants in current study. The samples of TSP were taken in June for 17 measurement sites by two records per site and then were obtained the average. The values of polluted gases measurement represent the average value for each site.

\section{Results and Discussion TSP}

The results of measurement TSP in air of Nahrawan bricks factories, as in Table (1), the highest concentration has been recorded at site No.(3), $\left(9801.7 \mu \mathrm{g} / \mathrm{m}^{3}\right)$ and the lowest concentration at site No.(13) $\left(386.2 \mu \mathrm{g} / \mathrm{m}^{3}\right)$. 
Average concentration of TSP in air of study area was $\left(2687.5 \mu \mathrm{g} / \mathrm{m}^{3}\right)$. The concentration of TSP in all measurement sites was much higher than WHO standard was $\left(150 \mu \mathrm{g} / \mathrm{m}^{3}\right)$. Compared to concentration TSP in air of the study area, with its in air of village of Nahrawan $\left(315.8 \mu \mathrm{g} / \mathrm{m}^{3}\right)$, as we note the presence of increasing high TSP in air of bricks factories as a result of the intensity of released pollutants to air from chimneys of bricks that use fuel oil to complete production of bricks. Due to the burning process is nonstandard and the absence of a central processing unit appropriate, height is adequate for the stacks in order to allow dispersion full of pollutants. As well as impact of suspended dust flying from the soil comminuted discourage wind and, passage of heavy vehicles and loading and unloading operations lead to the spread of dust in the air, especially on working days; and all these lead to increased concentration TSP in the air of the study area.

\section{CO}

Recorded the highest concentration of $\mathrm{CO}$ in the study site No. (1), (37.3 ppm), while lowest concentration at site No. (16), (4.9 ppm), showed Table (1). The average of $\mathrm{CO}$ in air of study area reached (19.7 ppm), exceeding WHO standard $(9 \mathrm{ppm})$ for exposure one hour, also note that most of the sites of measurement have exceeded WHO standard to $\mathrm{CO}$ concentration. When comparing $\mathrm{CO}$ concentration in the study sites with concentration in air of the village of Nahrawan was $(0.8 \mathrm{ppm})$, note the great difference in the $\mathrm{CO}$ concentration, because of the broad industrial activity in the bricks factories, which consumes large amounts of fuel oil to complete the process of producing bricks. $\mathrm{CO}$ arises from the incomplete combustion of fuel, so increased its concentration in most study sites, especially within the prevailing wind direction (northwest).

\section{$\mathrm{CO}_{2}$}

The highest concentration of $\mathrm{CO}_{2}$ has been recorded at site No.(2) was (390 ppm) and the lowest concentration was recorded at site No. (17) (276 ppm), showed Table(1). The average of $\mathrm{CO}_{2}$ concentration in of study area has reached to (336 ppm), higher than WHO standard was $(250 \mathrm{ppm})$. All study sites have been exceeded WHO standard of $\mathrm{CO}_{2}$ concentration, which indicates the presence of pollution of $\mathrm{CO}_{2}$ in air of the factories. When comparing $\mathrm{CO}_{2}$ concentration in the study sites with $\mathrm{CO}_{2}$ concentration in air of Nahrawan village (198 ppm), noted significant increase of the concentration of $\mathrm{CO}_{2}$, as a result of burning fuel intensive for the production of bricks, as well as the lack of vegetation, which contributes to increasing rates of $\mathrm{CO}_{2}$ in the current study.

\section{$\mathrm{SO}_{2}$}

Table (1) showed the highest concentration of $\mathrm{SO}_{2}$ in air of the study area was $(0.1 \mathrm{ppm})$ that recorded in several locations, while the lowest $\mathrm{SO}_{2}$ concentration was (0.0) in (9) measurement sites. The average of $\mathrm{SO}_{2}$ concentration $(0.05 \mathrm{ppm})$, which is higher than WHO standard was $(0.01 \mathrm{ppm})$, also noted that $\mathrm{SO}_{2}$ concentration in the sites had exceeded WHO standard. As well as exceeded concentration of $\mathrm{SO}_{2}$ in air of Nahrawan village, this recorded (0.0). The high concentration of $\mathrm{SO}_{2}$ in bricks factories, due to burning of fuel oil from about 200 bricks factories within a limited area. 
Table (1)

Concentrations of air pollutants and values of wind speed in Nahrawan bricks factories.

\begin{tabular}{|c||c||c|c||c||c|c||}
\hline Sites No. & $\begin{array}{c}\mathbf{T S P} \\
\mathbf{\mu g} / \mathbf{m}^{3}\end{array}$ & $\begin{array}{c}\mathbf{C O} \\
\mathbf{p p m}\end{array}$ & $\begin{array}{c}\mathbf{C O}_{2} \\
\mathbf{p p m}\end{array}$ & $\begin{array}{c}\mathbf{S O}_{\mathbf{2}} \\
\mathbf{p p m}\end{array}$ & $\begin{array}{c}\mathbf{N O}_{2} \\
\mathbf{p p m}\end{array}$ & $\begin{array}{c}\mathbf{W . S} \\
\mathbf{m} / \mathbf{s e c}\end{array}$ \\
\hline $\mathbf{1}$ & 1069.7 & 37.3 & 312 & 0.1 & 0.1 & 1.2 \\
\hline $\mathbf{2}$ & 3419.8 & 35.6 & 390 & 0.1 & 0.1 & 0.9 \\
\hline $\mathbf{3}$ & 9801.7 & 36.4 & 367 & 0.1 & 0.3 & 0.7 \\
\hline $\mathbf{4}$ & 1709.6 & 34.2 & 333 & 0.0 & 0 & 0.8 \\
\hline $\mathbf{5}$ & 5017.5 & 25.4 & 318 & 0.1 & 0.2 & 1.0 \\
\hline $\mathbf{6}$ & 8201.1 & 23.9 & 380 & 0.0 & 0.1 & 0.9 \\
\hline $\mathbf{7}$ & 1714.6 & 27.1 & 349 & 0.0 & 0.1 & 1.1 \\
\hline $\mathbf{8}$ & 2019.6 & 28.5 & 325 & 0.1 & 0.2 & 0.7 \\
\hline $\mathbf{9}$ & 4245.2 & 19.5 & 315 & 0.1 & 0.1 & 1.3 \\
\hline $\mathbf{1 0}$ & 4111.1 & 15.2 & 369 & 0.0 & 0.1 & 1.1 \\
\hline $\mathbf{1 1}$ & 819.6 & 12.4 & 355 & 0.1 & 0.2 & 1.3 \\
\hline $\mathbf{1 2}$ & 500.3 & 9.4 & 346 & 0.0 & 0.0 & 1.8 \\
\hline $\mathbf{1 3}$ & 386.2 & 7.1 & 342 & 0.1 & 0.1 & 1.5 \\
\hline $\mathbf{1 4}$ & 913.5 & 5.9 & 337 & 0.0 & 0.0 & 1.2 \\
\hline $\mathbf{1 5}$ & 701.7 & 6.6 & 310 & 0.0 & 0.0 & 0.9 \\
\hline $\mathbf{1 6}$ & 625.3 & 4.9 & 290 & 0.0 & 0.0 & 0.8 \\
\hline $\mathbf{1 7}$ & 432.4 & 5.8 & 276 & 0.0 & 0.0 & 1.3 \\
\hline \hline Average & 2687.5 & 19.7 & 336 & 0.05 & 0.09 & --- \\
\hline \hline Nahrawan village & 315.8 & 0.8 & 198 & 0.0 & 0.0 & 0.5 \\
\hline \hline WHO standard & 150 & 9 & 250 & 0.01 & 0.11 & --- \\
\hline \hline
\end{tabular}

$\mathrm{NO}_{2}$

The results of the study, showed Table (1), that the highest concentration of $\mathrm{NO}_{2}$ in air of the study area was $(0.3 \mathrm{ppm})$ and record in site No.(3), while the lowest concentration recorded (0.0) in (6) sites. The average of $\mathrm{NO}_{2}$ concentration in study sites was $(0.09 \mathrm{ppm})$, is slightly less than WHO standard $(0.11 \mathrm{ppm})$. Also noted that the study sites, which recorded the existence of $\mathrm{NO}_{2}$ were higher than their concentration in Nahrawan village, which did not record the presence of any concentration of $\mathrm{NO}_{2}$, due to $\mathrm{NO}_{2}$ is produced from the combustion of the fuel used in bricks factories, as well as heavy vehicles that are downloaded and unloading, which helps in high concentration of $\mathrm{NO}_{2}$ in air of study area.

\section{Spatial Analysis}

ArcGIS 10 software used to produce maps using spatial analyst option, surface interpolation functions to create a continuous surface from sampled point values. The continuous surface of raster dataset represents concentration of TSP and polluted gases in current study. The next step to create a spatial model of air pollutants concentration in Nahrawan is reclassifying data that means replacing input cell values with new output cell values based on air pollutants concentration for creating new rasters [12].

The cell values of each input raster are multiplied by the rasters weights to produce the final spatial model to air pollutants released by Nahrawan bricks factories as shown in Fig.(2). The sites $(8,5,3)$ recorded a high concentration of various air pollutants during the current study are most affected by these pollutants which the bricks factories is main source of air pollution and soil in the study area.

Fig.(3) demonstrates the use of spatial analysis to represent the values of wind speed recorded in study sites, as we note that the highest wind speed recorded at sites $(17,13,12)$, which lies north of the study area, while the lowest wind speed in central and southern regions. This shows the influence of wind speed in the spread of pollutants in the 
air as the increase in wind speed accompanied by a decrease in the concentration of pollutants and vice versa, where you wind the transfer of various air pollutants emitted from sources towards the prevailing wind. The prevailing wind direction in the study area is northwest and this is explains that the highest concentration of air pollutants in the current study has been recorded in central and southern regions for the bricks factories which are located towards the prevailing wind.

The impact of pollutants emanating from the Nahrawan bricks factories on workers and their families who live in the study area, as observed during the field investigation. A great number of children living in the area were of poor health, and a significant portion of the population were infected with various diseases, especially respiratory illness, due to the permanent presence near the factories and constant exposure to various air pollutants emanating from bricks factories.

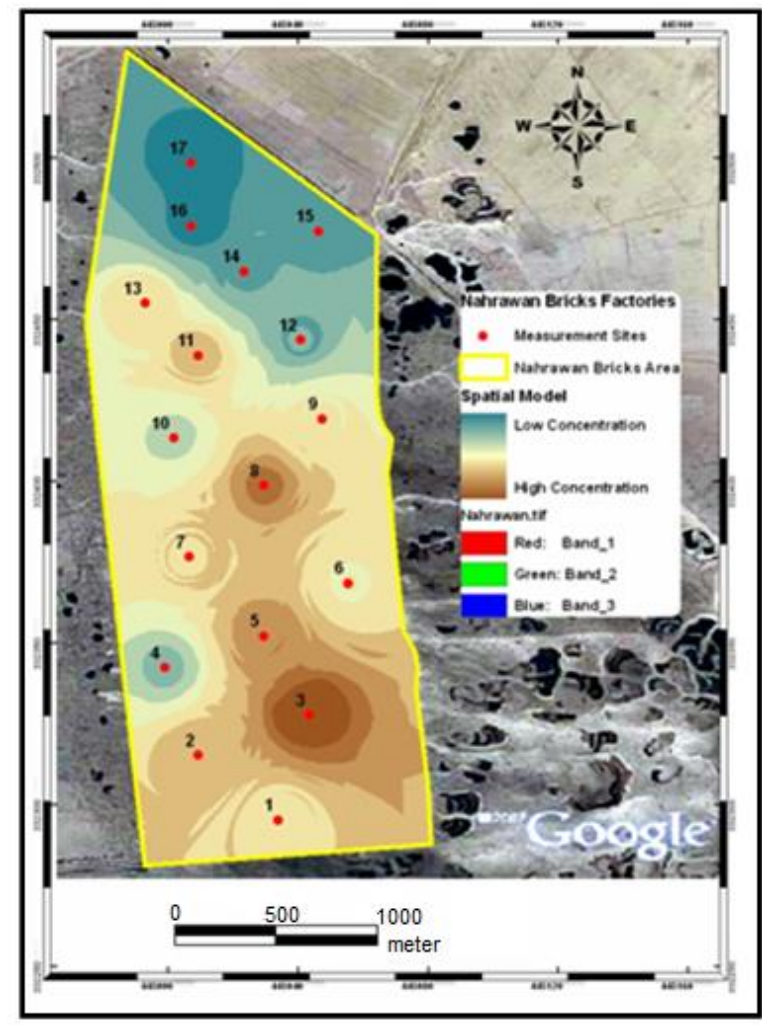

Fig.(2): Spatial model of air pollutants released by Nahrawan bricks factories.

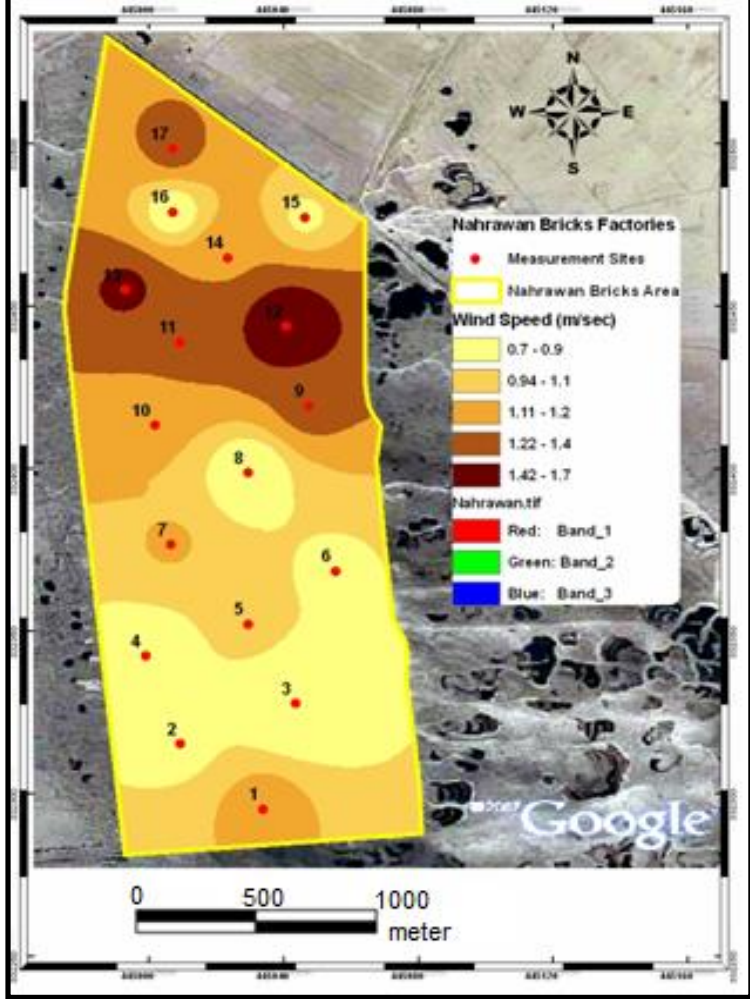

Fig.(3): Spatial analysis of wind speed recorded Nahrawan bricks factories.

\section{Conclusion}

The industrial process represents by brick and tanning factories considered the main reason for high level of pollutants in Nahrawan area. The results contain the air of Nahrawan bricks factories high concentration of TSP, as its concentration exceeded WHO standard in all study sites, as well as in air of Nahrawan village. The industrial processes that represent the bricks factories are the main reason to pollution. Most bricks factories do not have automatic combustion systems to reduce air pollution caused by fuel combustion, and not used filters to reduction of air pollutants emission. Replace natural gas by fuel oil in bricks industry, due to natural gas is clean fuel and low emission of gases pollutants. Arc GIS air pollution maps can be used as a basis for proper distribution of appropriate locations of air pollution measurement stations. The results of spatial analysis showed that the highest concentration of pollutants recorded in the study sites located to the central and southern to Nahrawan bricks factories, towards the prevailing wind. 


\section{References}

[1] Shakir, A. and Mohammed, A., "Manufacturing of Bricks in the Past, in the Present and in the Future: A state of the Art Review". International Journal of Advances in Applied Sciences (IJAAS), 2 (3), 145156, 2013.

[2] Sanjel, S., Thygerson, S. M., Khanal, S. N. and Joshi, S.K., "Environmental and Occupational Pollutants and Their Effects on Health among Brick Kiln Workers". Open Journal of Safety Science and Technology, Scientific Research Publishing Inc., 6, 81-89, 2016.

[3] Skinder, B., Pandit, A., Sheikh, A. and Ganai, B., "Brick kilns: Cause of Atmospheric Pollution". Journal of Pollution Effect and Control, 2 (2), 2014.

[4] Desonie, D., "Atmosphere: Air Pollution and Its Effects". Chelsea House Publisher, New York, USA, 208, 2007.

[5] Lazaridis, M., "First Principles of Meteorology and Air Pollution". Springer, USA, 373, 2010.

[6] Al-Sultany, A. R.; "Pollution of Air \& Soil in Nahrawan Area East Baghdad by Heavy Metals Produced From Brick Factories"; M.Sc. thesis; Geology Dept.; Collage of Science; Baghdad University; pp 119; 2006.

[7] EL Essa, A., "Continuation and Activation of Air Pollution of Brick Factories in Karbala Governorate". Scientific Journal of Karbala University, 9 (2), 30-45, 2011.

[8] Mazumdar, M. and Debnath, A., "Impact of Air Pollution on Human Rights (an Empirical Study on Select Brick Kilns of Palasbari Revenue Circle)". International Journal of Applied Research, 2 (8), 648656, 2016.

[9] Song S. J., "A GIS based Approach to Spatio-Temporal Analysis of Urban Air Quality in Chengdu Plain", The International Achieves of the Photogrammetry, Remote Sensing and Spatial Information Sciences, Beijing, 37 (7), 2008.

[10] Flores, J. W., "Analysis of Air Pollutants Presents in a Bricks Factory at Carabayllo District, Lima". Journal of Energy and Environment Sciences, Centre of Research and Training for Regional Development, 1 (1), 2017.
[11] IPCS, "Environment Health Criteria 165: Inorganic Lead". Geneva; WHO, 300, 1995. [12] ESRI, "Arc GIS 10: Using Geostatistical Analyst”. Redland: ESRI Press, 2013. 